Original Article

\title{
EFFECT OF MOMORDICA CHARANTIA AND SYZYGIUM CUMINI EXTRACT ON SERUM ELECTROLYTES IN ALLOXAN INDUCED DIABETIC RATS
}

\author{
G. NAVYA, Y. SHIRISHA, P. GIRIJA, K. VENKATESHWARLU, K. SIRISHA*
}

Department of Pharmaceutical Analysis, Vaagdevi College of Pharmacy, Ramnagar, Hanamkonda, Warangal 506001, Telangana, India Email: ragisirisha@yahoo.com

Received: 25 Jan 2018 Revised and Accepted: 04 Oct 2018

\begin{abstract}
Objective: Diabetes is a group of disorders characterized by high blood glucose levels. Disturbances in serum electrolytes like sodium (Na+) and potassium $\left(\mathrm{K}^{+}\right)$are found in diabetes. The purpose of the study was to investigate the disturbances in concentrations of serum electrolytes in hyperglycemic crisis and the effect of syzygium cumini and momordica charantia standardized aqueous extracts on serum electrolytes (Na+and $\mathrm{K}^{+}$) in normal and diabetic rats.
\end{abstract}

Methods: Diabetes is induced by intraperitoneal injection of alloxan at a dose of $120 \mathrm{mg} / \mathrm{kg} \mathrm{b}$. w in rats. Rats were divided into 5 groups (normal control, disease control, metformin, test 1 and test 2). In test groups 1 and 2, SASESC (standardized aqueous seed extract of syzygium cumini) and SAFEMC (standardized aqueous fruit extract of momordica charantia) were respectively administered orally to alloxan induced diabetic rats, and their serum electrolyte levels were observed at $1^{\text {st }}, 4^{\text {th }}, 7^{\text {th }}$ and $14^{\text {th }}$ days.

Results: By the $14^{\text {th }}$ day, the $\mathrm{Na}^{+}$and $\mathrm{K}^{+}$levels in groups 4 and 5 were almost normal. However, in group 3 (standard), Na+ levels were relatively lower and $\mathrm{K}^{+}$levels were relatively higher than groups 4 and 5 (test). In group 2 (disease control) as compared to group 1 (normal control), a decrease in $\mathrm{Na}^{+}$and increase in $\mathrm{K}^{+}$levels was observed even on day 14.

Conclusion: Treatment with anti diabetic drugs like metformin, syzygium cumini (test-1), momordica charantia (test-2) restored the electrolyte levels almost back to normal over a period of study $(14 \mathrm{~d})$. There was significant $(* * \mathrm{P}<0.01, * \mathrm{P}<0.05)$ normalization of electrolyte levels in diabetic rats. It was concluded that syzygium cumini and momordica charantia showed better efficiency in restoring the electrolyte imbalance as compared to metformin during our study.

Keywords: Syzygium cumini, Momordica charantia, Metformin, Diabetes, Electrolyte, Alloxan

(c) 2018 The Authors. Published by Innovare Academic Sciences Pvt Ltd. This is an open-access article under the CC BY license (http://creativecommons.org/licenses/by/4.0/] DOI: http://dx.doi.org/10.22159/ijpps.2018v10i11.24963

\section{INTRODUCTION}

Diabetes mellitus (DM) is a group of metabolic diseases characterized by high blood glucose level (hyperglycemia) resulting from defects in insulin secretion, insulin action, or both. The chronic hyperglycemia of diabetes is associated with long-term damage, dysfunction, and failure of various organs like the eyes, kidneys, nerves, heart, and blood vessels [1,2]. Electrolytes are salts in the body that conduct electricity and are found in fluid, tissue and blood. A proper balance of electrolytes such as sodium $\left(\mathrm{Na}^{+}\right)$, potassium $\left(\mathrm{K}^{+}\right)$, calcium $\left(\mathrm{Ca}^{2+}\right)$, magnesium $\left(\mathrm{Mg}^{2+}\right)$ and others are essential for overall health. They have a pivotal role in the maintenance of homeostasis inside the body, regulation of heart and brain function, body fluid balance, ventilation, pH etc [3]. Deficiency or imbalance of electrolytes can lead to serious conditions. DM is amongst those diseases which show frequent disturbances of electrolytes and acidbase relations, especially in patients with deranged renal function and other end-organ injury, mal-absorption syndromes, acid-base imbalances and multiple drug regimens and medications for DM management. The knowledge and insight of the disease process and its management would create the way for 'pathophysiology-directed therapy', leading to prevention of the several adverse effects associated with acid-base and electrolyte disorders and their management [4-8].

Alterations of ionized $\mathrm{Na}^{+}, \mathrm{K}^{+}$, and $\mathrm{Mg}^{+}$in the serum have been reported in DM subjects, both as causes and consequences. There is also increasing evidence that electrolyte imbalances are early biochemical events responsible for long-term diabetic complications. Considerable variations in the electrolyte metabolism may exist in populations depending on the genetic constitution, nutritional status, and environmental situation. It has been suggested that alterations in $\mathrm{Na}^{+}, \mathrm{K}^{+}, \mathrm{Ca}^{2+}$ and other biologically relevant elements might occur due to malfunction of $\mathrm{Na}^{+}-\mathrm{K}^{+}$pumps. There is increasing evidence that these alterations of electrolytes across the cell may play a vital role in the mechanism of cellular injury leading to retinopathy, nephropathy, and neuropathy in DM subjects [9]. The present study was chosen to investigate the serum levels of $\mathrm{Na}^{+}$and $\mathrm{K}^{+}$in alloxan-induced diabetic rats without any complications.

Drugs used to treat DM like metformin and sulfonylureas along with tricyclic antidepressants (used to treat neuropathy) can also cause electrolyte and acid-base disturbances. In modern medicine, no satisfactory effective therapy is available to control DM along with electrolyte imbalance. The literature survey reveals that anti-diabetic herbs have the capacity to cure electrolyte imbalance along with DM [10-13]. In this regard, an herbal anti-diabetic drug used traditionally viz., momordica charantia and syzygium cumini were chosen for the present study to investigate a possible effect of the standardized aqueous fruit extract of momordica charantia (SAFEMC) and standardized aqueous seed extract of syzygium cumini (SASESC) on the serum electrolytes in alloxan-induced diabetic rats.

\section{MATERIALS AND METHODS}

\section{Drugs and chemicals}

SAFEMC and SASESC were procured from navachethana kendra Pvt. Ltd, Delhi and Shree narnarayan ayurvedic pharmacy, Ahmedabad, Gujarat, India respectively. Alloxan monohydrate was purchased from Chemit Labaratories, Hyderabad, India. Metformin was purchased from nice chemical Pvt. Ltd, Cochin, and India. The glucose estimation kit was purchased from Vijaya diagnostics; Hanamkonda, India and all other chemicals used in this study were obtained commercially and were of analytical grade. 


\section{Animals}

Female wistar albino rats (150-220 g) were obtained from mahaveer enterprises, Hyderabad, India. The rats were housed in a temperature of $25 \pm 1{ }^{\circ} \mathrm{C}$ and relative humidity of $45-55 \%$ under 12:12 light-dark cycle. The animals had free access to food pellets and water ad libitum. The experimental protocol was approved by the institutional animal ethics committee (IAEC), vaagdevi college of pharmacy, Warangal (NO: 2015/7/5/2) and performed in accordance with the guidelines of the committee for control and supervision of experimentation on animals (CPCSEA), Government of India on animal experimentation.

\section{Experimental induction of diabetes mellitus [10]}

Various methods are reported for the induction of DM. Amongst them, alloxan was chosen for the induction of type 2 diabetes in the present study. Diabetes was induced in overnight fasted rats using alloxan monohydrate dissolved in normal saline by intraperitoneal injections (120 mg/kg b. w). After 48 h, blood glucose levels were measured using glucose kits.

\section{Grouping of animals for pharmacokinetic study}

Rats were divided into 5 groups containing six animals in each group $(\mathrm{n}=6)$

GROUP-1: Normal animals received water and normal standard pellet diet (normal control).

GROUP-2: Diabetic animals received water and normal standard pellet diet (disease control).

GROUP-3: Diabetic animals received metformin (500 mg/kg b. w.) dissolved in methanol.

GROUP-4: Diabetic animals received SASESC (250 mg/kg b. w.) orally suspended in sodium carboxymethyl cellulose [test 1]

GROUP-5: Diabetic animals received SAFEMC (250 mg/kg b. w.) orally suspended in sodium carboxymethyl cellulose [test 2]

\section{Collection of blood samples}

Blood samples were collected from retro-orbital vein puncture under diethyl ether anesthesia on 1st, 4th, 7thand14th days. Before the collection of blood samples, animals were fasted for $16 \mathrm{~h}$ with water ad libitum.

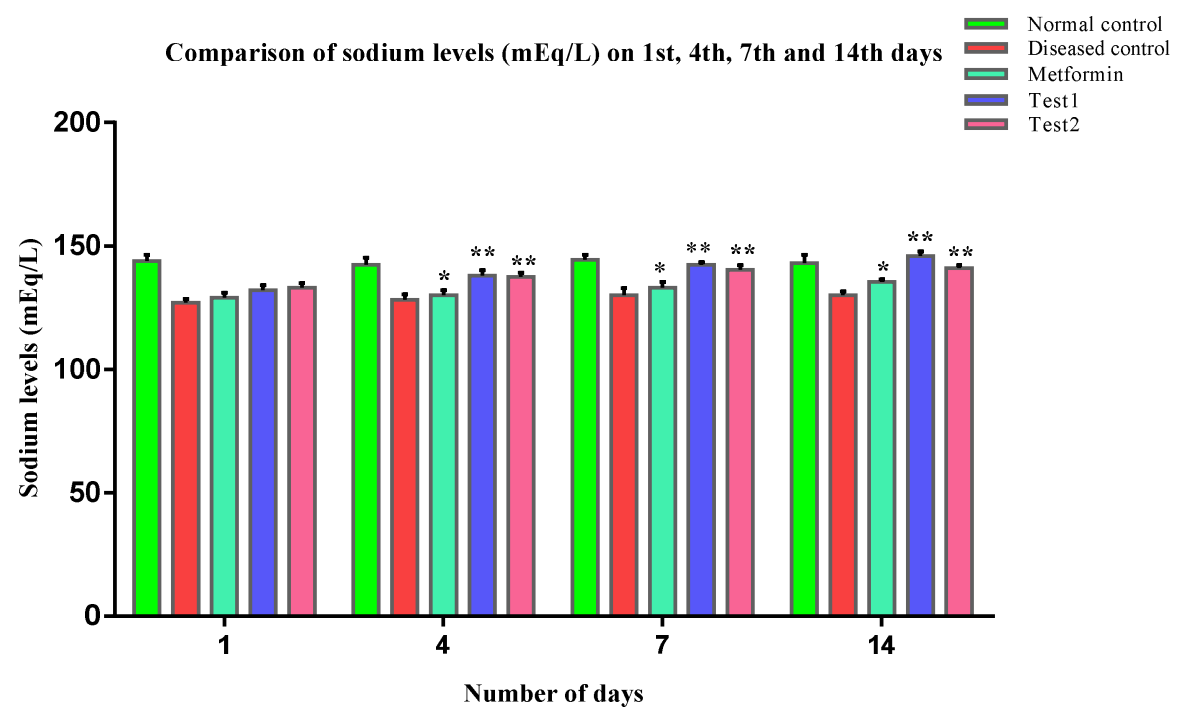

Fig. 1: Graphical representation of sodium levels. All values were expressed as mean $\pm \mathrm{SD}, \mathrm{n}=6,{ }^{* *} \mathrm{P}<0.01, * \mathrm{P}<0.05$ as compared to the disease control group. The results were done by one-way ANOVA followed by dunnett's test

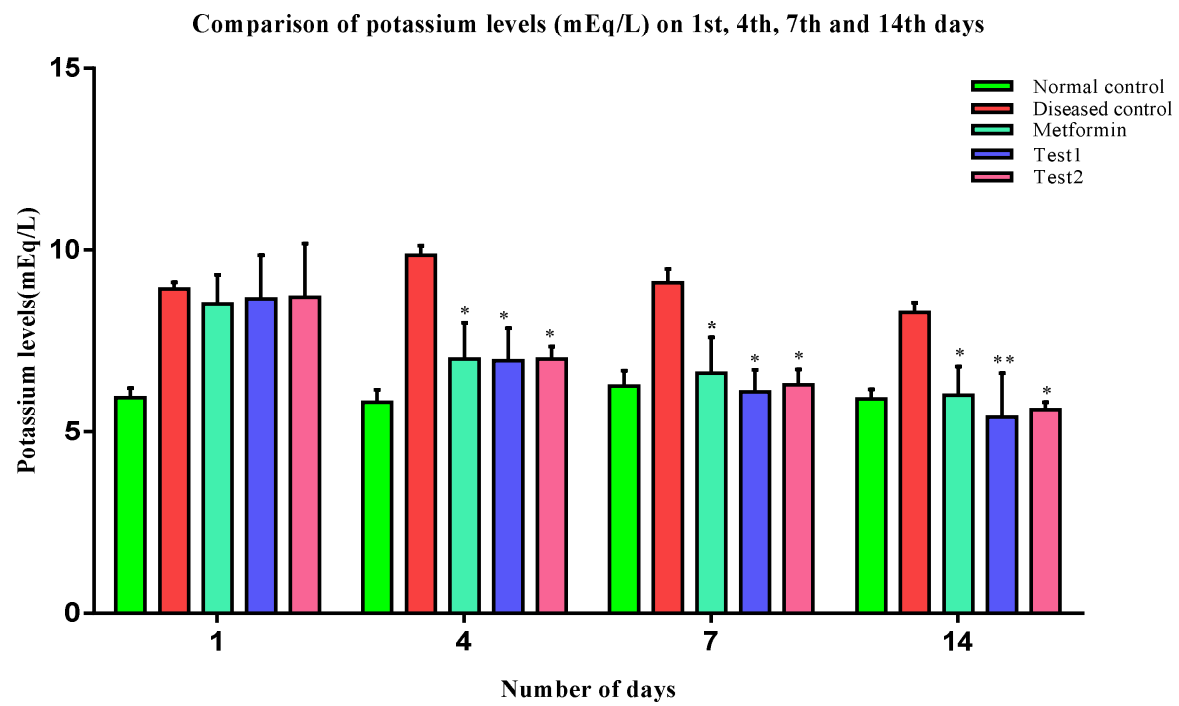

Fig. 2: Graphical representation of potassium levels. All values were expressed as mean $\pm \mathrm{SD}, n=6, * * \mathrm{P}<0.01, * \mathrm{P}<0.05$ as compared to the disease control group. The results were done by one-way ANOVA followed by dunnett's test 


\section{Preparation of serum samples for pharmacokinetic study}

$1 \mathrm{ml}$ of blood samples were collected from each animal in each group and transferred into $1.5 \mathrm{ml}$ eppendrofs tubes. Tubes were vortex mixed for $1 \mathrm{~min}$, centrifuged at $13000 \mathrm{rpm}$ for $15 \mathrm{~min}$. The supernatants were transferred into clean, similarly labeled tubes and were stored at- $20^{\circ} \mathrm{C}$ until use. All the samples were analyzed for electrolytes $\left(\mathrm{Na}^{+}\right.$and $\left.\mathrm{K}^{+}\right)$by Erba Chem, autoanalyzer.

\section{Statistical analysis}

All the data were statistically evaluated by ANOVA (one way), and the differences among groups were determined by dunnett's multiple comparison tests using graph pad prism 7.0. Values were considered to be significant when ${ }^{* *} \mathrm{P}<0.01,{ }^{*} \mathrm{P}<0.05$. All the results were presented as mean \pm SD for six rats in each group.

\section{RESULTS}

Fig. $1 \& 2$ shows significant $\left({ }^{* *} \mathrm{P}<0.01,{ }^{*} \mathrm{P}<0.05\right.$ level of significance) increase in $\mathrm{Na}^{+}$levels and decrease in $\mathrm{K}^{+}$levels of groups 4 and 5 which were treated with SASESC and SAFEMC at a dose of 250 $\mathrm{mg} / \mathrm{kg}$ in alloxan Induced diabetic rats over a period of $14 \mathrm{~d}$.

\section{DISCUSSION}

Derangement of water and electrolyte balances might occur in groups with DM, resulting from insulin deficiency, elevated levels of glucose and ketone bodies in the blood [14]. The current study showed a major reduction in serum $\mathrm{Na}^{+}$and an elevation in serum $\mathrm{K}^{+}$in DM group. This result was consistent with those reported by previous studies [15-17].

The pancreatic $\beta$ cells were destroyed using alloxan, a toxic glucose analogue that accumulates in the pancreatic beta cells via GLUT 2 glucose transporter in the presence of thiols especially glutathione (GSH), Alloxan generates reactive oxygen species (ROS) in a cyclic redox reaction. The reduction product of alloxan is dialuric acid. Auto-oxidation of dialuric acid generates ROS, which are responsible for the death of the $\beta$ cells [18-22].

Serum electrolyte concentrations are among the most commonly used laboratory tests by clinicians for the assessment of a patient's clinical condition and disease state. $\mathrm{Na}^{+}$and $\mathrm{K}^{+}$are among the most commonly monitored electrolytes in clinical practice. Serum $\mathrm{Na}^{+}$ levels were observed to decrease significantly following diabetic induction. Glucose excretion in urine by diabetics imposes an osmotic diuresis or dehydration. With the consequence of electrolyte lost with dehydration in hyperglycemia the elevated serum glucose concentration result in high serum osmolarity, thus creating an osmolar gradient between the plasma compartment and the extracellular fluid leading to a shift of water into the intravascular space, the net effect is a dilution of the serum $\mathrm{Na}^{+}$concentration resulting in hyponatremia [23].

Patients with hyponatremia associated with low total body $\mathrm{Na}^{+}$often exhibit signs and symptoms of dehydration. These manifestations include thirst, dry mucous membrane, weight loss, sunken eyes, diminished urine output, and diminished skin. $\mathrm{K}^{+} \mathrm{can}$ move out of and into cells. The blood test measures the $\mathrm{K}^{+}$that is present outside of the cell. Therefore, conditions that can cause $\mathrm{K}^{+}$to to move out of the cells into the blood circulation can increase the blood $\mathrm{K}^{+}$level even though the total amount of $\mathrm{K}^{+} \mathrm{in}$ the body does not change.

One example of $\mathrm{K}^{+}$shift causing hyperkalemia is diabetic ketoacidosis. The acidosis and high glucose level in the blood work together to cause fluid and $\mathrm{K}^{+}$to move out of the cell into the blood circulation. Patients with DM often also have diminished kidney capacity to excrete $\mathrm{K}^{+}$into urine. The combination of $\mathrm{K}^{+}$shift out of cell and diminished urine $\mathrm{K}^{+}$excretion causes hyperkalemia [17].

It is clearly evident that herbs have vast potential to produce bioactive compounds that can be developed into antidiabetic agents. Despite this potential, antidiabetic plants remain grossly understudied and under-utilized as a source of novel medication, particularly within the developed countries [24].

One of the major objectives of the present study was to investigate the effect of the herbal extract on serum $\mathrm{Na}^{+}, \mathrm{K}^{+}$levels in DM subjects.
Although the present investigation covers only a section of normal healthy rats and diabetic rats, it will give important methodological and technical standardization for further studies in this field. It may also have a beneficial impact on clinical practice. The present study was carried out for $14 \mathrm{~d}$ in rats, and the level of serum electrolytes are observed on $1^{\text {st }}, 4^{\text {th }}, 7^{\text {th }}$ and $14^{\text {th }}$ days and electrolyte levels were analyzed by using autoanalyzer.

Fig. 1 and 2 displays the readings of $\mathrm{Na}^{+}$and $\mathrm{K}^{+}$electrolytes from $1^{\text {st }}$ to $14^{\text {th }}$ days on different groups along with their mean and standard deviation. The results on day 1 revealed that alloxan injection has led to a decrease in $\mathrm{Na}^{+}$levels and increase in $\mathrm{K}^{+}$levels in the disease control, standard and test groups. However, antidiabetic drugs like metformin, momordica charantia and syzygium cumini could restore the $\mathrm{Na}^{+}$and $\mathrm{K}^{+}$levels almost back to normal values over a period of $14 \mathrm{~d}$, thus indicating their ability to treat electrolyte imbalance.

Further, treatment with herbal antidiabetic drugs like syzygium cumini and momordica charantia displayed better efficiency in restoring the electrolyte imbalance as compared to metformin during our study. Hence, they can be recommended for the treatment of type 2 DM where they can effectively reduce the elevated glucose levels and subsequently treat the electrolyte imbalance, which is otherwise seen in DM with lesser side effects which could be advantageous over the synthetic drugs usage.

\section{CONCLUSION}

Good glycemic control and electrolyte balance are usually enough for preventing and treating complications in DM. Electrolyte imbalance has a significant effect upon the risk of contracting many diseases. From the results obtained in the present study, it can be concluded that SASESC and SAFEMC can regulate $\mathrm{Na}^{+}$and $\mathrm{K}^{+}$levels in alloxan-induced diabetic rats. Hence, these extracts can treat DM without affecting serum electrolytes, which is otherwise encountered in marketing synthetic drugs.

\section{ACKNOWLEDGMENT}

The authors would like to thank the Principal and Management of Vaagdevi College of pharmacy, Warangal for providing the necessary facilities to carry out this work.

\section{AUTHORS CONTRIBUTIONS}

G. Navya and Y. Shirisha gave a substantial contribution by executing the experimental work in our laboratories. Dr. K. Venkateshwarlu and Mrs. P. Girija drafted the manuscript and extensively revised to improve the quality of the manuscript. Conception, the design of the study and supervision of the work were done by Dr. K. Sirisha.

\section{CONFLICTS OF INTERESTS}

The authors declare no conflicts of interest

\section{REFERENCES}

1. Clinical practice guidelines expert committee. Diagnosis, classification, and diagnosis of diabetes, pre-diabetes and metabolic syndrome. Can J Diabetes 2013;37:S8-11.

2. Diagnosis and classification and diagnosis of diabetes mellitus. Diabetes Care 2010;33:S62-9.

3. Wikipedia contributors. Wikipedia, the Free Encyclopedia. San Francisco: Wikimedia Foundation, Inc; 2004.

4. Talabani N. Serum electrolytes and lipid profile in non-insulin dependent diabetes mellitus patients. Asian J Med Sci 2014;6:38-1.

5. Liamis G, Liberopoulos E, Barkas F, Elisaf M. Diabetes mellitus and electrolyte disorders. World J Clin Cases 2014;2:488-6.

6. Sotirakopoulos N, Kalogiannidou I, Tersi M, Armentzioiou K, Sivridis D, Mavromatidis Kl. Acid-base and electrolyte disorders in patients with diabetes mellitus. Saudi J Kidney Diseases Transplantation 2012;23:58-2.

7. Biff FP, Deborah JC. Electrolyte and acid-base disturbance in patients with diabetes mellitus. New Eng J Med 2015;373:548-9.

8. Husain F, Arif Maan M, Sheikh MA, Nawaz H, Jamil A. Trace elements status in type 2 diabetes. Bangladesh J Med Sci 2009;8:52-6. 
9. Lowery JM, Eichberg J, Saubermann AJ, LoPachin RM. Distribution of elements and water in peripheral nerve of streptozocin-induced diabetic rats. Diabetes 1990;39:1498-3.

10. Nabeel MS. Effect of an extract of phoenx dactylifera palm leaves on some blood serum electrolytes in alloxan induced female rats. Int J Adv Res 2014;2:731-6.

11. Agoda PO, Braide VB. Effect of dietary garcinia kola seed on serum electrolytes and trace elements in male albino rats. J Physiol Sci 2011;24:53-7.

12. Omigie IO, Agoreyo FO. Effects of citrullus lanatus seed on blood glucose and electrolyte parameters in diabetic induced Wistar rats. J Appl Environ Management 2014;18:231-3.

13. Singh N, Gupta M. Ethanolic extract of syzygium cumini seed powder on pancreatic islets of alloxan diabetic rats. Indian J Exp Biol 2007;45:861-7.

14. Kitabchi AE, Umpierre GE, Murphy MB, Kriesberg RA. Hyperglycemic crisis in adult patients with diabetes: a consensus statement from the American diabetes association. Diabetes Care 2006;29:2739-8.

15. Wang S, Hou XH, Liu Y, Lu HJ, Wei L, Bao YQ, et al. Serum electrolyte levels in relation to macrovascular complications in Chinese patients with diabetes mellitus. Cardiovasc Diabetol 2013;12:146-6.

16. Haglin L, Backman L, Tornkvist B. A structural equation model for assessment of links between changes in serum triglycerides, urate, and glucose and changes in serum calcium, magnesium, and phosphate in type 2 diabetes and nondiabetes metabolism. Cardiovasc Diabetol 2011;10:116-4.

17. Uribarri J, Oh MS, Carroll HJ. Hyperkalemia in diabetes mellitus. J Diabet Complications 1990;4:3-7.

18. Shanmugasundaram ER, Rajeswari G, Baskaran K, Rajesh Kumar BR, Radha Shanmugasundaram K. Use of gymnema sylvestre leaf extract in the control of blood glucose in insulin-dependent diabetes mellitus. J Ethnopharmacol 1990;130:281-4.

19. Sheweita SA, Newairy AA, Mansour HA, Yousef MI. Effect of some hypoglycemic herbs on the activity of phase I and II drugmetabolizing enzymes in alloxan-induced diabetic rats. Toxicology 2002;174:131-9.

20. Srikanta S, Gando O, Eisenbarth G, Stoeldner J. Islet-cell antibodies and beta-cell function in monozygotic tripleta and twins initially discordant for type I diabetes mellitus. N Engl J Med 1983;388:322-5.

21. Torres IC, Suarez JC. A preliminary study of hypoglycemic activity of lythrum salicaria. J Nat Prod 1980;43:559-3.

22. Veiga F, Fernandes C, Teixeira F. Oral bioavailability and hypoglycemic activity of tolbutamide/cyclodextrin inclusion complexes. Int J Pharm 2000;202:165-1.

23. Liamis G, Liberopoulos E, Barkas F, Elisaf M. Diabetes mellitus and electrolyte disorders. World J Clin Cases 2014;2:488-6.

24. Ngugi MP, Njagi MJ, Kibiti MC, Ngeranwa JNJ, Njagi NME, Njue MW, et al. Herbal management of diabetes mellitus. Int J Curr Pharm Res 2012;2:1-4. 